\title{
The role of residential fabric in the configuration of the city in Spain in the 1940s and 1950s. The case of Jaca
}

\author{
Raimundo Bambó Naya \\ Escuela de Ingeniería y Arquitectura. Universidad de Zaragoza. Zaragoza, Spain \\ E-mail: rbambo@unizar.es
}

\begin{abstract}
The housing problem was one of the fundamental concerns of the new State that emerged after the Civil War in Spain. Different official bodies were created to this end, facing the need for reconstruction of different cities and villages and the dwelling shortage. A series of residential projects of different nature were developed in towns and cities, modifying their urban configuration. The aim of this work is to study different public housing group projects carried out during the 1940s and 1950s in the city of Jaca (Aragon) by Lorenzo Monclús, Municipal Architect of the city, Regional Delegate of the National Housing Institute and Urban Planner. On the one hand, the study focuses on the theoretical models on which they are based, the building types, the architectural language, and the design of the urban space. On the other hand, on the adaptability of these models to the existing city structure and its planning: a 1917 Extension Project according to nineteenth century models, carried out after the demolition of the city walls, and revised on successive occasions during the studied period. This analysis of a local experience is part of a wider debate: that of the urban culture in Spain during the postwar period. Despite all the limitations, modern functionalist urbanism was assimilated through public housing projects and urban extensions with open edification in smaller settlements, with techniques akin to those used in larger cities throughout the country.
\end{abstract}

Keywords: Residential fabric, public housing, city extensions, Jaca (Aragon)

\section{Public housing in Spain in the autarky years}

The housing problem was one of the fundamental concerns of the new State that emerged after the Civil War in Spain. The need to rebuild or renovate the housing stock of damaged towns and cities was added to the dwelling shortage that already existed during the dictatorship of Primo de Rivera and the Second Republic. Therefore, during the autarky years (1939-1959) the New State radicalized its interventionist policy in housing that had been previously initiated (SolàMorales, 1976, 20-22). It also incorporated a strategic intention, since giving access to the working class to decent housing would involve neutralizing one of their demands, contributing to the consolidation of peace and social stability (Lasso de la Vega, 2008, 44). Different official bodies were created to this end, formed mainly by a group of young architects who studied in the 1930s: The Directorate General for Devastated Regions (Dirección General de Regiones Devastadas, DGRD) was responsible for the reconstruction of housing, urban equipment, infrastructures and settlements, where the reestablishment of the residential fabric was an important work. The National Colonization Institute (Instituto Nacional de Colonización, INC) was at the forefront of the modernization of rural areas. The Unions Housing Project (Obra Sindical del Hogar, $\mathrm{OSH}$ ) was responsible for implementing public social policy programs on housing (Sambricio and Sánchez Lampreave, 2008). 
As for the National Housing Institute (Instituto Nacional de la Vivienda, INV), it was the body in charge of coordinating the entire State housing strategy. Among its many functions was to define the legal framework from which the actions of the aforementioned bodies would take place (Lasso de la Vega, 2008). The INV regulations determined the conditions to be met by each dwelling: total area, number and minimum area of the different rooms, or lighting, orientation and ventilation conditions. But it also laid down several regulations for groups of residential units. Thus, the types of blocks and the minimum distances between them were defined. Also, densities, areas of free spaces per inhabitant, or streets conditions: their width, paving, vegetation, etc. (Instituto Nacional de la Vivienda, 1939). Both the regulations relating to the housing unit and its grouping allowed some freedom in composition, but were very strict in functional issues. The language used in the housing groups built these years has sometimes led to qualify this architecture as afar from the principles of modernity, but hidden behind its classicist or regionalist facades we can find processes intrinsic to modern functionalism, which prove the knowledge of the research developed in the architectural and urban culture of Central Europe in the 1920s and 1930s (Solà-Morales, 1976, 26-29).

From these regulations drafted by the INV, different public bodies - the described ones, but also local administrations - carried out numerous operations of public housing and urban extensions. The housing typologies used would determine a series of different residential fabrics, an essential component of the city, understanding both buildings and their linked public spaces as part of the fabric (López de Lucio, 2013). This issue is more clearly identified in the projects carried out in smaller settlements, where techniques akin to those used in larger cities were used. The work developed by the Higher Urban Planning Commission of the province of Zaragoza (1957), which established building standards for eight different areas, can serve as an example. Five of these areas corresponded to residential use: old town, closed block, open block, isolated building and agricultural building - the other three being disseminated agricultural construction, industrial area and green area-. The same range of types is used in other parts of the country, like the plans of the contemporary Urban Planning Commission of the province of Barcelona, both in line with the ordinances of Berlin of 1925 (Gigosos, 1983, 127). The city is thus conceived as a mosaic built step by step from different residential units, each one generating a different type of urban fabric with its own characteristics.

Among the members of this Commission was Lorenzo Monclús Ramírez, Regional Delegate of the INV, Urban Planner and Municipal Architect of the city of Jaca (Aragon), where he designed several public housing groups in the $40 \mathrm{~s}$ and $50 \mathrm{~s}$. The aim of this work is to study these groups: on the one hand, the theoretical models on which they are based, the building types, the architectural language, and the design of the urban space, On the other hand, on the adaptability of these models to the existing city structure and its planning. Before studying these groups, we will briefly go over the urban history of the city between 1900 and 1950.

\section{Jaca in the first half of the 20th century}

The city of Jaca is located in the first foothills of the Aragonese Pyrenees. Its location, $25 \mathrm{~km}$ from the French border and in the valley of the Aragon river - the only great valley parallel to the axis of the Pyrenean chain- makes the settlement a strategic enclave, which had a major impact on its urban history. The city was constrained by its walls until the beginning of the 20th century, which led to health and hygiene problems. This situation changed when in 1902 permission was granted to demolish the walls surrounding the city, justified by its inefficiency as a defensive element and the population growth (Yeste, 1991, 20). It would be authorized in 1914, taking place a year later. It would result in the drafting of the City Extension Project in December 1917 by Francisco Lamolla Morante, following the concession to Jaca of the benefits of the Madrid and Barcelona City Extension Act of 
1892 (Buesa, 2002, 266). The City Extension Project comprised two main areas, west and north, as well as an Interior Reform Plan for the old town, not contemplating the possible growth of the city to the south or southeast beyond the plateau where the settlement sits. The Project took as a starting point the link of old roads, railway lines and main accesses to the city. It also established the general regulations that new constructions should follow (Yeste, 1991, 23). The western area was relatively regular, but the northern area opted for a more complex layout, generated from the superposition of an orthogonal grid with diagonal lines communicating new squares, inspired by approaches close to the City Beautiful movement. Therefore, most of the resulting blocks were triangular or trapezoidal, an issue Lamolla (1917) justified by stating that symmetry and right angle were "procedures that practice has sanctioned as defective" (Figure 1).

Lorenzo Monclús drafted successive revisions of this City Extension Project (Bambó, 2016, 287-295). The first one, in 1944, consisted in the modification of the layout of the west area, to accommodate the constructions that had been built not following the alignments of Lamolla. The second, carried out between 1945 and 1952, reconsidered the northern area, seeking maximum regularity in the blocks, without relinquishing the singularity of squares located at strategic points. In addition, Monclús proposed a zoning plan of the whole of the city. The issue of zoning had been addressed by Gabriel Alomar (1947), who synthesized the knowledge and theories about the matter in Spain at that time (Terán, 1978, 232-236). Monclús established a division in high and low-density housing areas, industry and green zones, drawing the different roads according to their hierarchy (Figure 2 ). Therefore, following almost literally the orthodox functionalist precepts established by the Athens Charter, and the zoning of the city in areas for living, working, recreation and circulation.

This city extension in transformation was be the domain on which Monclús designed the housing groups, stablishing a different relation in each one of them. Some proposals were autonomous, like small peripheries totally independent of the existing or projected urban structure, while others were understood in continuity with the layout, defining the encounter of the City Extension with the historical centre and with the city limits.

\section{Group of 34 protected housing units}

This group promoted by the municipality of Jaca consists of 34 single-family detached houses, being the most important residential operation built outside the historic centre so far. It is located far away from city centre, towards the north. It occupies a sloping terrain falling towards the east, exceeding the plateau boundary on which the city lies, outside the limits of the Lamolla City Extension Project.

The group is organized around a central road connecting the two streets that limit the site. The geometry of this road is conditioned by the topography - straight when the terrain is horizontal, curved in the greater slope - and by the few existing trees. The housing plots are arranged on both sides, being of variable geometry to adapt to the terrain (Figure 3 ). This new street is the only public space of the group, with different conditions along its length: the first horizontal section has wider sidewalks and two lines of trees. The sidewalks narrow and the trees disappear in the sloping section, except in its central part, where there is a widening also with trees. Thus, there is a degree of privacy in the free space of the group: from a public walk in the encounter with the city extension to an almost private road, which presents a small common space in its central section. Despite this, the whole group seems to be inserted in a large park: the division of the plots is made with low height fences or hedges, so there is a visual fusion of the public vegetation with the one of the private yards.

Monclús designs two types of housing, of three and four bedrooms. Both locate day areas on the ground floor, and bedrooms on the first. He uses a hybrid language between vernacular architectures, heterodox rationalisms, and Central European Alpine architectures present in the magazines of its library, like Moderne 


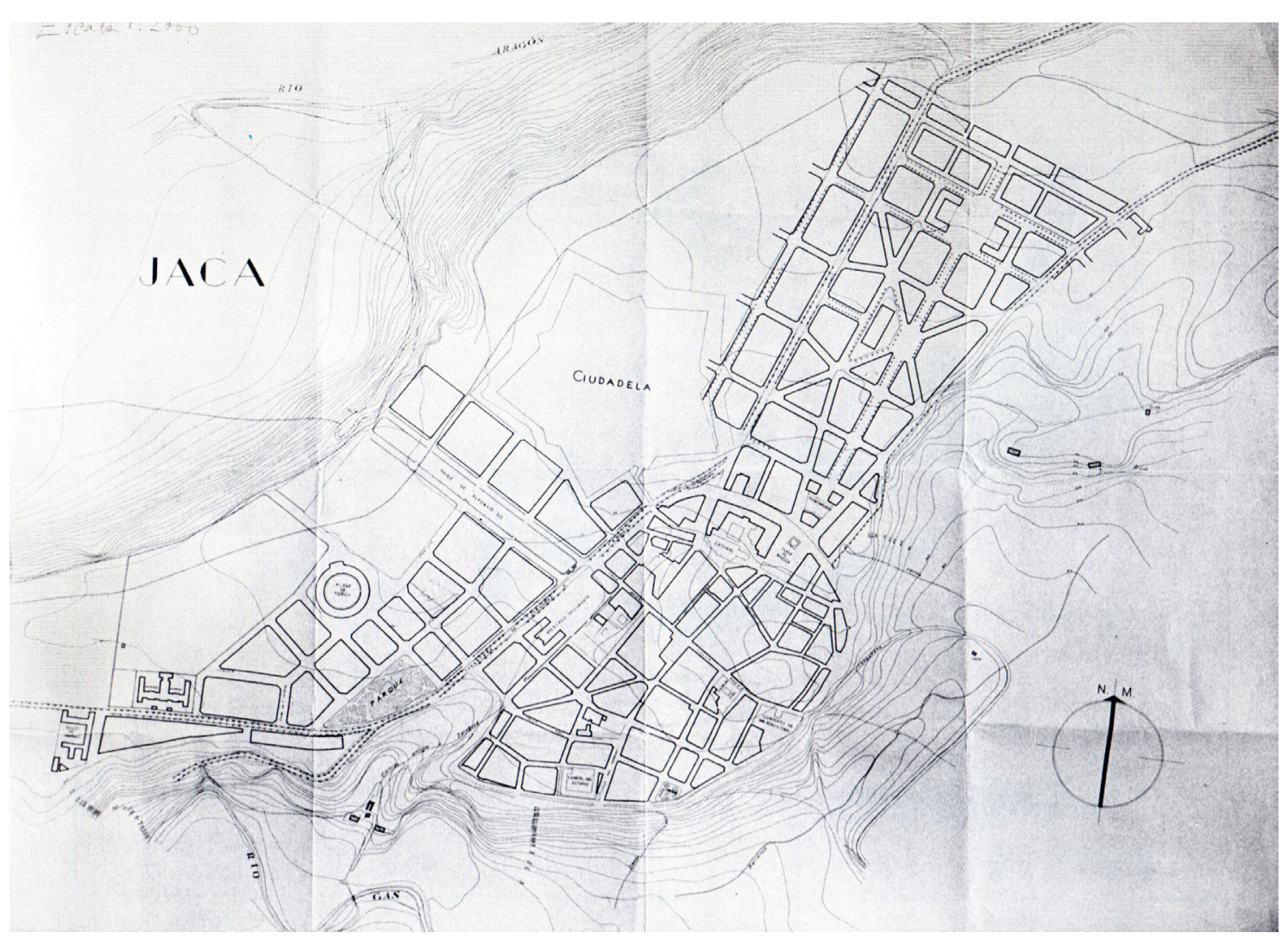

Figure 1. Francisco Lamolla, Plan for the Extension of Jaca (Aragón), 1917.

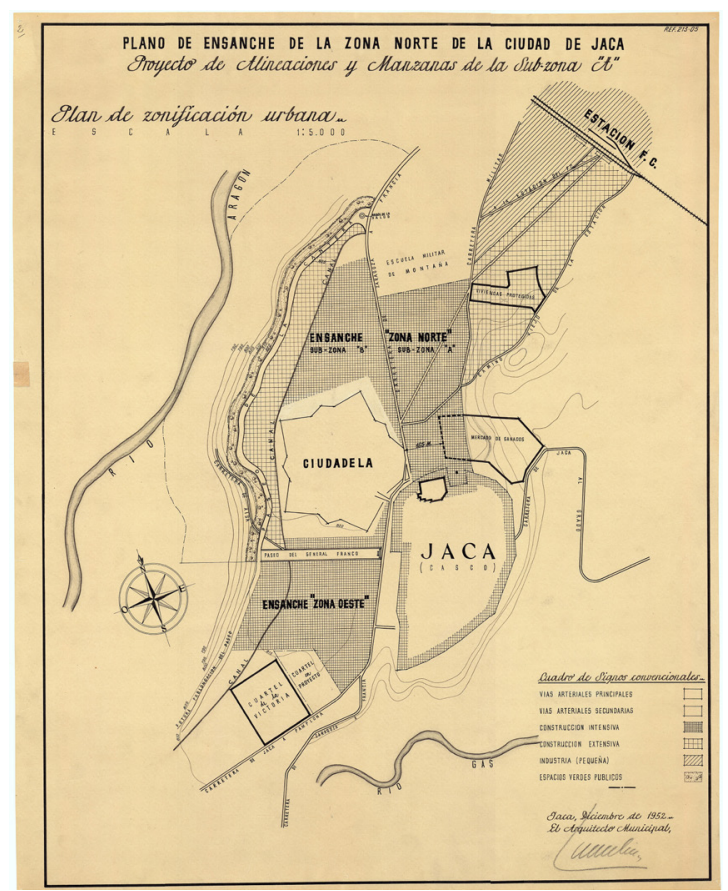

Figure 2. Lorenzo Monclús, Zoning plan of Jaca (Aragón), 1952.

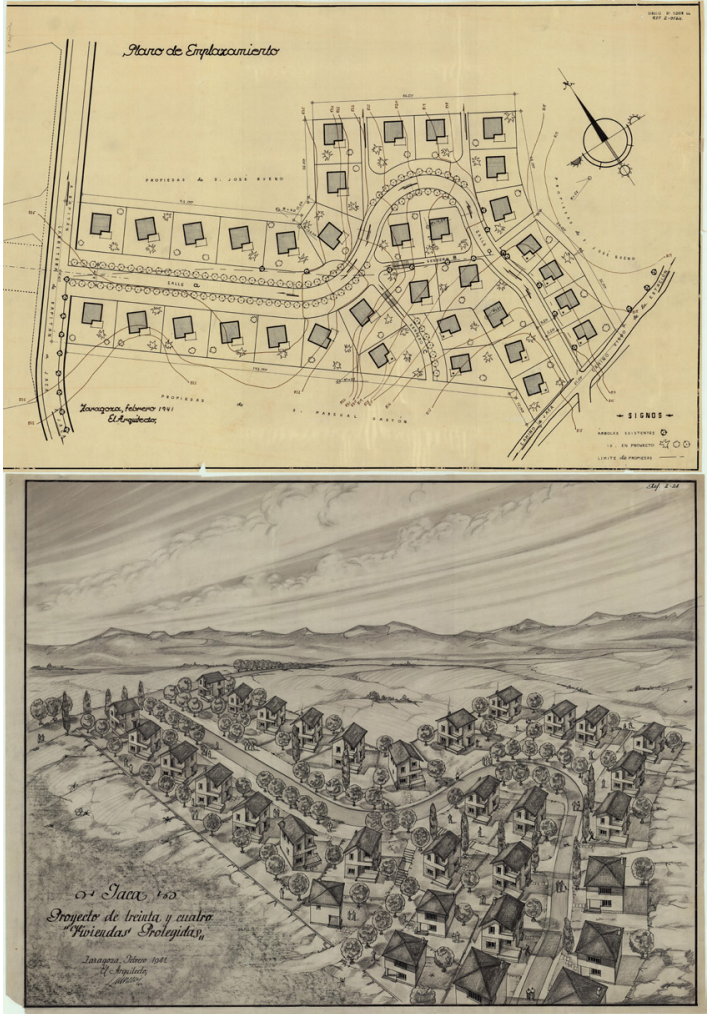

Figure 3. Lorenzo Monclús, Group of 34 protected housing units, Jaca (Aragón), 1941. 
Bauformen, Monatshefte für Baukunst und Städtebau, L'Architecture d'Aujourd'hui or Architettura (Bambó, 2016, 131-133). The street does not condition the organization of the houses: they are arranged in strict function of the orientation, with the main rooms facing south, and with slight turns to adapt the buildings to the topography, always within the margins allowed by the regulations. Thus, any of the house façades can indistinctly face the street, giving the group a certain picturesque character. This makes it impossible to speak of front yard and backyard, contributing to the isotropy of the whole.

The housing type, the relative distance of the city centre, and the homogeneity and autonomy of the plot, gives to the group some characteristics of a garden city, or rather, a garden suburb, a more appropriate term to this kind of groups that aroused in Spain early in the century as an alternative to the popular subdivisions and middle-class extensions (Monclús and Bergera, 2012, 34), carried out based on the Cheap Housing (Casas Baratas) legislation (Arias, 2008).

\section{Group of 50 protected housing units}

In 1953, Monclús designs a second housing group for the city council. It is located partly on the land occupied by the livestock market. The location is optimal for several reasons: it is outside the city extension, but next to its east border, and close to the historical centre of the city. From the logistic point of view, its construction does not depend on the total dismantling of the market, since it does not affect its buildings, but it subtracts much of its area, limiting its functionality. In this way, it accelerates the process of its transfer to areas further away from the urban core, one of the demands of the city at the time. The main drawback, however, is the topography, with a difference of six meters between the limits of the terrain.

Monclús faces this situation with a strategy of fragmentation: the 50 housing units are distributed in 21 blocks of different length. $\mathrm{He}$ uses two types of housing: paired, and threestory blocks, with two dwellings per floor, which can be arranged on the available land with relative freedom. In the west, towards the city extension, the blocks are placed perpendicular to the street, equidistant, offering an ordered front. However, to the east he rotates the blocks, enabling their adaptation to the terrain, and looking towards the landscape. A new street crosses the group. Horizontal in its first section, it reaches the lower street level by a large staircase, of excessive dimensions for the scale of the group, not so much if it is considered as urban element of connection. In order to reinforce the idea of this street as part of the road network of the city, rather than as internal road of the group, it is flanked by two blocks of greater length and height. The rest of the free space is treated like a garden shared by the dwellings, unlike the previous group, where each housing unit had its own garden (Figure 4).

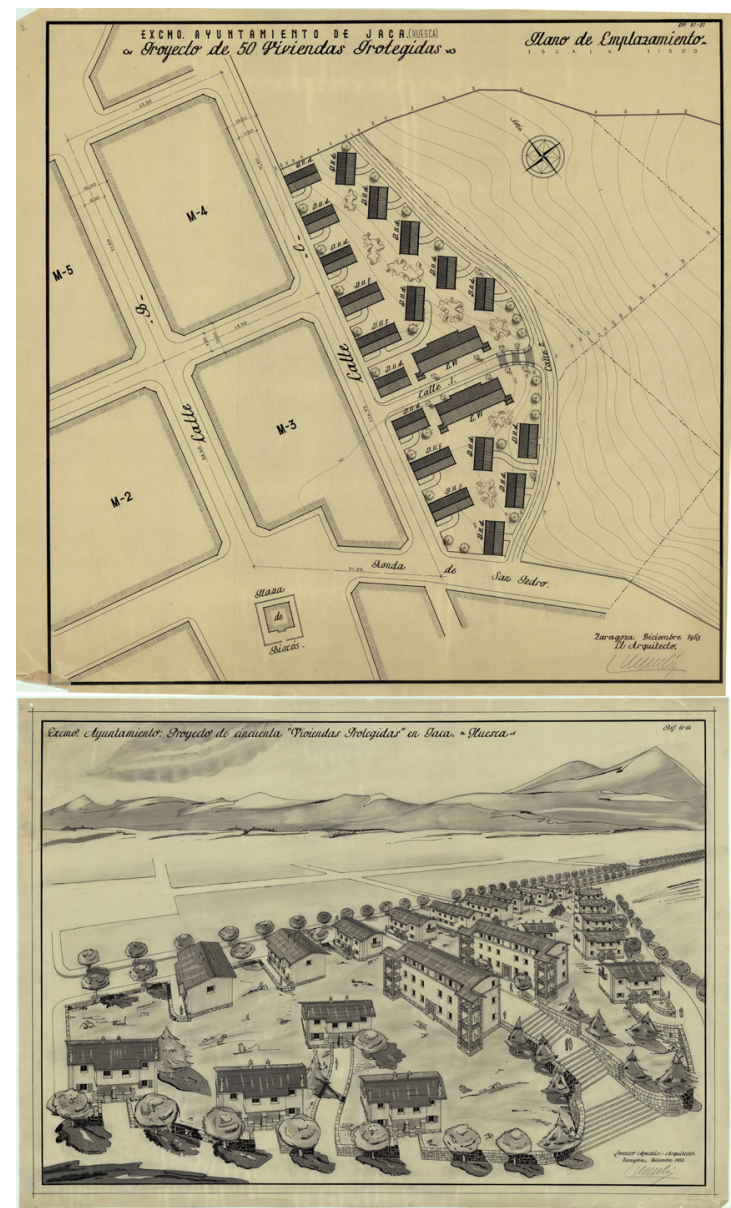

Figure 4. Lorenzo Monclús, Group of 50 protected housing units, Jaca (Aragón), 1953. 
In this group, geometry is used not only as a way to adapt to the topography and orientation, but as a response to an urban situation: following the direction of the city extension, and turning towards the landscape, presenting a more imprecise front in what will be for some years the new limit of the city.

\section{José Soto López de Uribe Group of 30 low- income housing units}

A year later, another group of public housing was developed, in collaboration with Mariano Lacarte: the José Soto López de Uribe group of 30 low-income housing units, in this case promoted by the OSH on a municipal plot next to the train station. They form part of the Union Trade Housing Plan (Plan Sindical de la Vivienda) for the years 1954-1955 (Sambricio, 2003).

The group consists of five equal three-story blocks that are arranged following the direction of the station's road, displaced between them, accommodating to the geometry of the site, also improving the sun exposure and allowing all the blocks to have views towards the landscape at the south (Figure 5). In the technical report of the project Monclús justifies this layout "according to the Jaca weather conditions and the location of the plot within the city extension. Both conditions advise an open urbanization and isolated blocks, which allows good sun exposure of each dwelling, with a traffic road on one side of the plot, and pedestrian paths from this road to each block." In this description, we can see the autonomous nature of the group, independent of the structure of the city. The free space is designed as a green area in its entirety, without any road between the blocks as in the previous cases, reinforcing this situation of isolation with respect to the surroundings. This also allows the group to adapt to a low-density housing environment, as planned in the 1952 Monclús Zoning Plan. The green area thus serve as a transition between single-family or semi-detached houses and blocks, avoiding sudden changes in the layout. Each block houses six triple orientation dwellings, with two dwellings per floor served by a staircase. All the dwellings follow the same model, one of those collected in the Plan Sindical (Sambricio, 2003). The dwellings are very simple and austere, assuring the optimal conditions of sun exposure and ventilation in all the rooms, optimizing the areas to the maximum, reducing for that purpose the circulations to the minimum possible. The same austerity can be seen in its formal appearance: five sober white prisms with gabled roofs.

\section{Group of 125 subsidized housing units and bus station}

The group of 125 subsidized housing units and bus station was the last one designed by Monclús in Jaca, in 1959. It is located next to the group realized in 1953, being the only group located in the north zone of the City Extension. It is facing the historic centre, occupying two blocks in front of the Biscós square. The group, promoted by the municipality of the city, benefited from the extension in 1958 to the whole country of the subsidized housing type, developed in the Social Emergency Plan of Madrid a year earlier.

If in previous projects the general layout was determined by the topography, orientation, views or even a certain will of picturesqueness, in this case it is the configuration of the city extension that shapes the layout. The group is formed by eight longitudinal buildings arranged in two blocks of the extension. Five of them are equal, perpendicular to the streets limiting the plot. The group finishes at its northern end with a C-shaped building. The front towards Biscós square has two buildings perpendicular to the rest, placing between them the new bus station [figure 6].

Biscós square, an important open space of Jaca since the sixteenth century, played a key role in the new structure of the city in the different expansion plans. Lamolla placed in front of it the new Town Hall, from which parted a trident of streets. Monclús discards this approach in his plan, but maintains the role of the square: is the beginning of a structuring street of the city extension; a new block of the extension, L-shaped, helps to enclose the urban space. The housing group reproduces this $\mathrm{L}$ shape with two blocks. The importance of this 


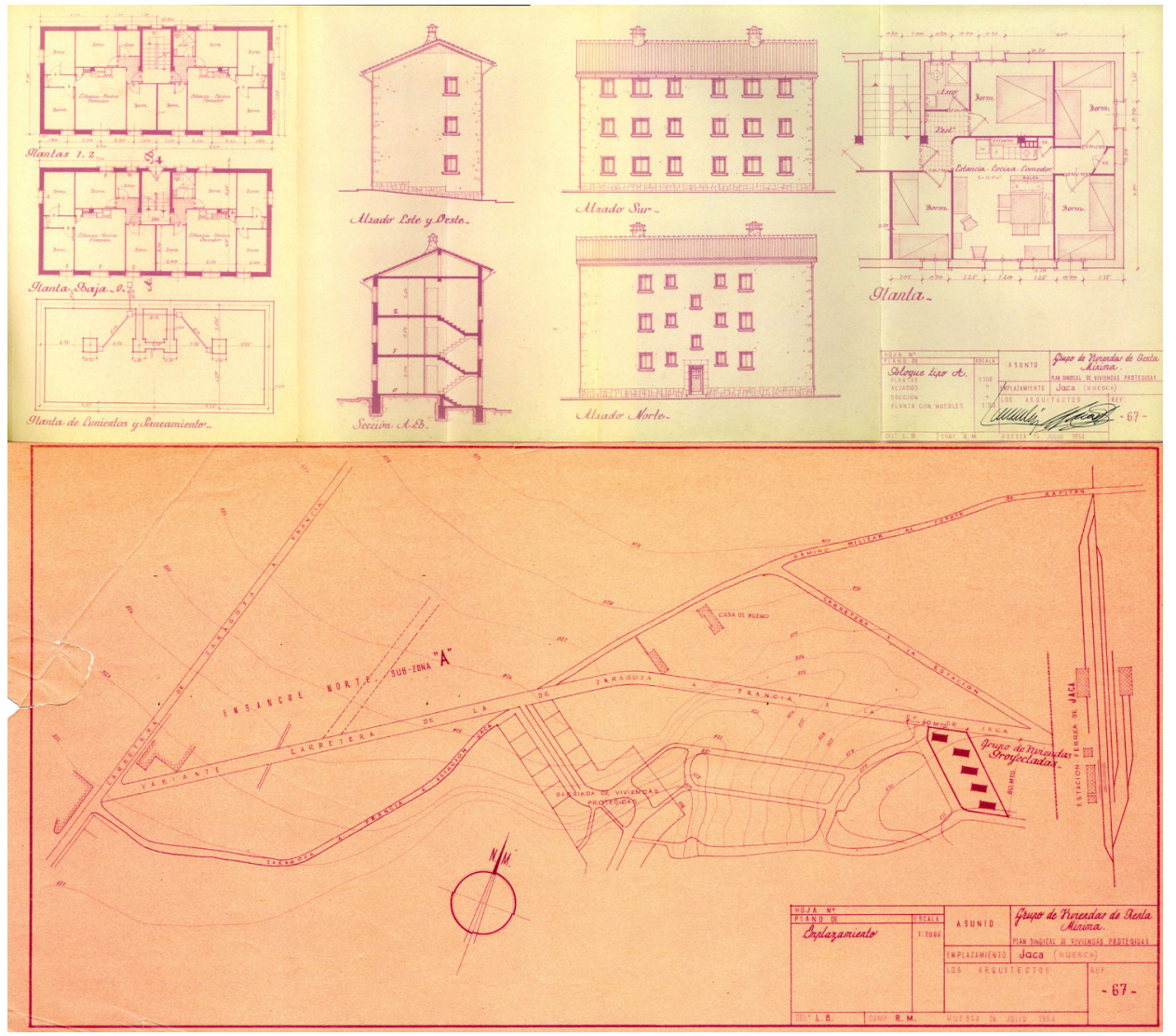

Figure 5. Lorenzo Monclús and Mariano Lacarte, José Soto López de Uribe Group of 30 low-income housing units, Jaca (Aragón), 1954.

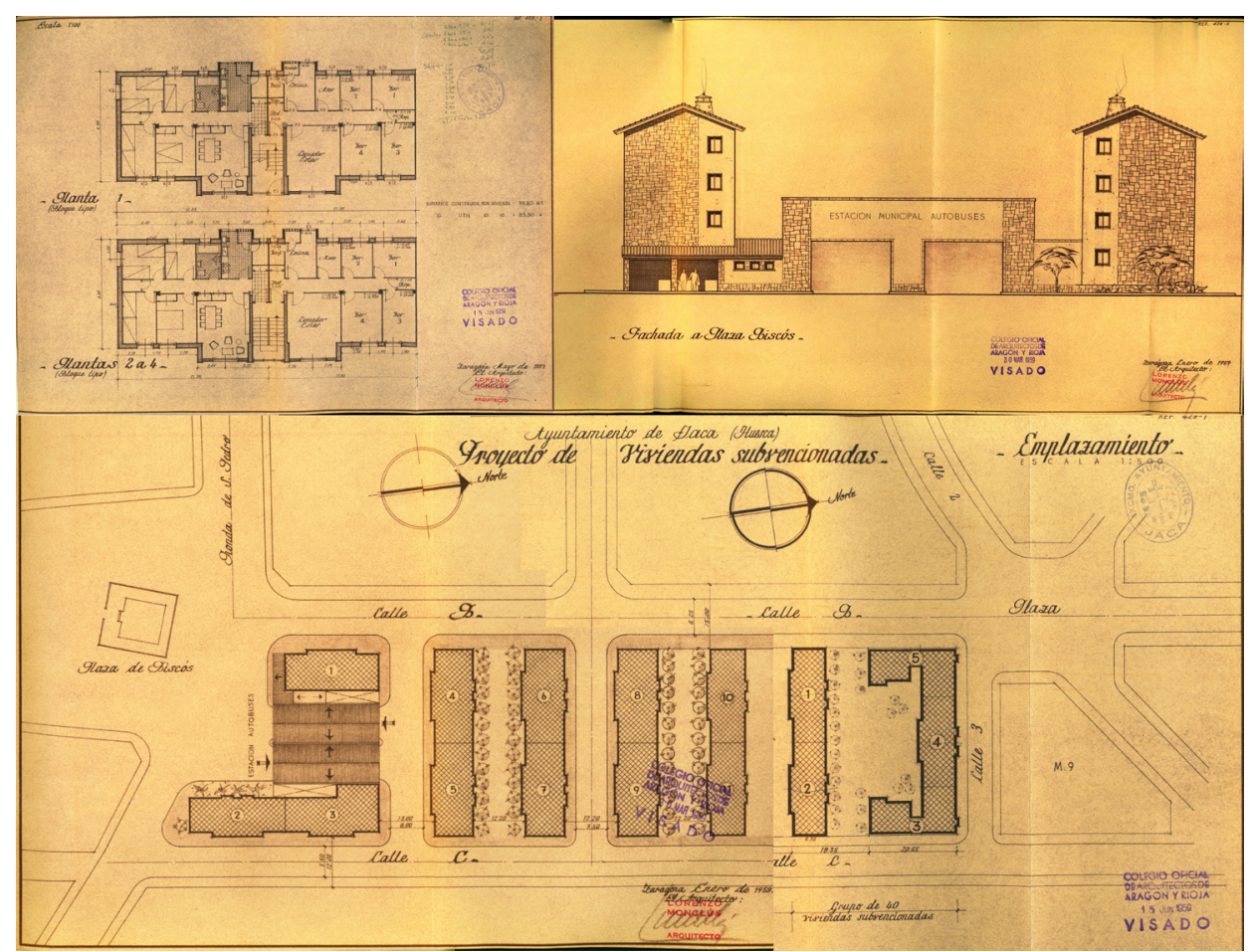

Figure 6. Lorenzo Monclús, Group of 125 subsidized housing units and bus station, Jaca (Aragón), 1959. 
point is highlighted by placing in front of the square the new urban equipment.

Monclús therefore uses an open block system, according to the definition of the INV regulations $(1939,65-66)$, with a $12 \mathrm{~m}$ separation between blocks, equal to the height of the buildings. In a similar way to the Soto López de Uribe Group justification, the technical report says: "For reasons of constructive economy, the layout in parallel four-story blocks has been preferred, allowing optimum orientation of one of the facades of all the dwellings, and wide-open spaces, with optimum sun exposure, fundamental in this mountain climate". The distance between buildings in the streets crossing the group is the same as in the garden areas that are located in the space between the rest of the buildings, so there is no spatial hierarchy of the free zones. The gardens, despite being opened to existing streets, have a private character, almost of an inner courtyard, since most of the pedestrian transits uses the streets to that cross the group. All buildings are four-story, and are shaped by adding modules composed of a central staircase serving two dwellings per floor. The layout of the dwelling is similar to those of the linear blocks of the previous examples: double orientation, cross ventilation, maximum functionality grouping wet rooms (kitchen and bathrooms) and separating day from night areas. The image is not very different from the previous examples, with walls partly cladded in stone.

\section{The continuity of the modern project}

The four groups constitute a set of eclectic character in formal and language issues, but that systematically uses a series of typologies that allows to solve multiple urban situations in an effective way. Except for the first case, made in 1942, all groups are shaped using linear blocks, with similar characteristics. It is a very efficient typology: its width, between 7 and 9 meters, guarantees optimal conditions for the dwellings, optimizing the structure and allowing schemes of maximum rationality. We have seen the urban versatility of the typology: different arrangements of these blocks with free green spaces between them can be used to configure blocks of a city extension, to solve the edges of the consolidated city, or to generate autonomous groups. The end of the 1950s would be the era for the emergence of large public housing estates with open blocks in Spain (López de Lucio, 2013, 119-143); Monclús would continue to explore this system in larger scale interventions than those carried out in Jaca (Díez Medina and Pérez Moreno, 2012).

It is therefore not surprising to find in Monclús' personal library Rationelle Bebauungsweisen (1931), the proceedings of the third CIAM held in Brussels in 1930, focused on rational land development. Its spirit is present in the INV regulations, like the one of the previous congress, devoted to the minimum dwelling. This tradition of modernist urbanism would be added to the influence of authors such as Patrick Abercrombie, Karl Brunner, Thomas Sharp, Frederick Gibberd, Gaston Bardet or Werner Hegemann, first hand known in the case of the first two for the publication of their work in Spanish (1936 and 1939), or by the influence on the theoretical production of César Cort, Gabriel Alomar, or in the courses of urbanism of the Institute of Local Administration Studies (Instituto de Estudios de la Administración Local, IEAL) (Gigosos, 1983, 125-126 and Terán, 1978, 232-246). We can therefore speak of a historical continuity with design methods of the 1920s and 1930s, including those of orthodox rationalism.

This analysis of a local experience is part of a wider debate: that of the urban culture in Spain during the postwar period. Despite all the limitations, modern functionalist urbanism was assimilated through public housing projects and urban extensions with open edification in smaller settlements, with techniques akin to those used in larger cities throughout the country.

\section{References}

Abercrombie, P. (1936) Planeamiento de la ciudad y del campo (Espasa Calpe, Madrid). Arias González, L. (2008) 'Las “Casas Baratas" (1911-1937), primer gran 
ensayo de vivienda social en España' in Sambricio, C. and Sánchez Lampreave, R. (eds.) La vivienda protegida. Historia de una necesidad (Asociación Española de Promotores Públicos de Vivienda y Suelo AVS, Madrid) 25-41.

Alomar, G. (1947) Teoría de la ciudad (Instituto de Estudios de la Administración Local, Madrid).

Bambó Naya, R. (2016) 'El dictado de los tiempos. Razón y oficio en la arquitectura de Lorenzo Monclús Ramírez', unpublished $\mathrm{PhD}$ thesis, Universidad de Zaragoza, Spain.

Brunner, K. (1939-1940), Manual de Urbanismo, 2 vols. (Bogotá: imprenta municipal).

Buesa Conde, D. (2002) Jaca. Historia de una ciudad (Ayuntamiento de Jaca, Jaca).

Comisión Superior de Ordenación Urbana de la provincia de Zaragoza (1957) Comisión Superior de Ordenación Urbana de la provincia de Zaragoza. 1950-1956 ([s.n.], Zaragoza).

Díez Medina, C. and Pérez Moreno, L. (2012) 'Balsas de Ebro Viejo', in AA VV Paisajes urbanos residenciales en la Zaragoza contemporánea (Prensas Universitarias de Zaragoza, Zaragoza), 60-63.

Gigosos, P. (1983) 'Los planes orgánicos de la Comisión Provincial de Barcelona', Quaderns d'arquitectura i urbanisme 157, 125-131.

Instituto Nacional de la Vivienda (1939). Normas y Ordenanzas. ([s.n.], Madrid).

Lamolla Morante, F. (1917) Proyecto de ensanche de la ciudad. Memoria descriptiva, ([s.n.], Jaca).

Lasso de la Vega Zamora, M. (2008) 'El Instituto Nacional de la Vivienda de Federico Mayo y José Fonseca', in Sambricio, C. and Sánchez Lampreave, R. (eds.) La vivienda protegida. Historia de una necesidad (Asociación Española de Promotores Públicos de Vivienda y Suelo AVS, Madrid) 43-71.

López de Lucio, R. (2013) Vivienda colectiva, espacio público y ciudad: Evolución y crisis en el diseño de tejidos residenciales (Nobuko, Buenos Aires).

Monclús Fraga, J. and Bergera Serrano, I. (2012) 'Ciudad Jardín', in AA VV Paisajes urbanos residenciales en la Zaragoza contemporánea (Prensas Universitarias de Zaragoza, Zaragoza) 34-37.

Rationelle Bebauungsweisen: Ergebnisse des 3. Internationalen Kongresses für Neues Bauen (1931) (Julius Hoffmann, Stuttgart)

Sambricio, C. (2003) 'El Plan Sindical de la Vivienda de 1955', in Sambricio, C. (ed.), Un siglo de vivienda social 1903-2003, volume II, (Madrid, Nerea) 59-61.

Sambricio, C. and Sánchez Lampreave, R. (eds.) (2008) La vivienda protegida. Historia de una necesidad (Asociación Española de Promotores Públicos de Vivienda y Suelo AVS, Madrid).

Solà-Morales i Rubio, I. de. (1976) 'La arquitectura de la vivienda en los años de la autarquía (1939-1953)', Arquitectura 199, 19-30.

Terán, F. (1978) Planeamiento urbano en la España contemporánea (Gustavo Gili, Barcelona).

Yeste Navarro, I. (1991) Evolución urbana de Jaca: [catálogo de la exposición celebrada en] Jaca, 17 octubre a 17 noviembre 1991, Palacio de Congresos (Diputación General de Aragón, Departamento de Cultura y Educación, Zaragoza). 